\title{
Benefits from Increasing Salary, Employee Benefits and Rank for Promotion the Nursing Shortage in Macao Chinese Society
}

\author{
Cindy Sin U Leong \\ School of Health Science, Macao Polytechnic Institute, Macao, China \\ *Corresponding Author: suleong@ipm.edu.mo
}

Copyright (C 2013 Horizon Research Publishing All rights reserved.

\begin{abstract}
The purpose of this study was to compare and discuss the modified policy for nursing staff in the public sector in Macao Chinese society. This study compared the past and present modifications in the bill of the Rank and Grade System in the public sector. The greatest concerns of the nursing staff included the old bill of rights, the grading system for the nursing staff, which needed to be modified, and improvements, especially with regard to salary, employee benefits and rank for promotion. The essential elements of the updated policy regarding salary (increasing from 22 to 43\%), employment benefits (increasing more than $100 \%$ based on tenure), on-shift allowance (flexible) and rank for promotion (number of ranks added) were adjusted. These improvements are not only beneficial on a personal and professional level but are also beneficial at the healthcare institution level, society level and academic nursing school level. Multiple levels of benefit detailed in the present study may provide a good impetus to end the nursing manpower shortage in the near future.
\end{abstract}

Keywords Nurse Staff, Policy, Salary, Employee Benefits

\section{Introduction}

The Macao Health Bureau, the largest public health care system in Macao, which is located in the southern part of Guangdong Province on mainland China, is managed and fully supported by the government. The Health Bureau is responsible for most health-care related services in Macao, providing all types of specialist treatments and acute care services in hospitals, infection control and prevention, education on health and food hygiene, tuberculosis prevention and treatment and other services in the public health sector and community facilities [1]. Because this organization is part of the public health sector, all of the health-care services are provided free to Macao residents except adults between the ages of 18 and 65. However, young adults with cancer, infectious diseases or low income that satisfies the baseline poverty requirement [2] can have their medical fees exempted. Even the primary health-care centers provide free services to all Macao residents. Because of the high coverage of health-care services for the majority of residents, the higher consumption of health-care services by older adults and the existence of a nursing manpower shortage, job satisfaction among the nursing staff is worsening. In addition, nursing staff salary has been increased in a long time. A local research study [3] showed that more than $96.6 \%$ of the nurses strongly agreed or agreed that the "salary and employee benefits should be increased". The nurses also agreed with statements such as the "salary and benefits did not keep up with inflation" (92.9\%), the "salary did not reflect their great responsibilities and pressure" (91.2\%), the facilities should "allocate more resources to the wages and benefits of the nurse" (96.4\%) and the "salary does not reflect educational qualifications" (89.3\%). Obviously, financial compensation [4], i.e., salary and employee benefits, is an excellent way to increase job satisfaction among frontline nursing staff. Economic factors are clearly the primary way to increase job satisfaction [5-8]. Other research studies showed that nurses are eager to increase their salary compared with their workload and the quality of care [9-11]. Other research outcomes revealed that employment benefits, health-care insurance and other factors needed to be improved in addition to financial compensation [6,12]. Hong Kong, which is $61 \mathrm{~km}$ from Macao, is not an exception. In hospitals with low staff salaries, $70 \%$ of the experienced nurses left for hospitals that offer higher salaries and better benefits [13-14]. Additional studies from different countries are summarized in Table 1. 
Table 1. Literature review

\begin{tabular}{|c|c|c|c|c|}
\hline $\begin{array}{l}\text { Author } \\
\text { (Year) } \\
\text { Country } \\
\end{array}$ & $\begin{array}{l}\text { Data source/ } \\
\text { Sample size }\end{array}$ & Methods/Measurement tools & Predictors/Themes & Main results \\
\hline $\begin{array}{l}\text { Dunaway } \\
\text { (2008),[15] } \\
\text { USA }\end{array}$ & $\begin{array}{l}350 \text { APNs in } \\
\text { Nevada }\end{array}$ & $\begin{array}{c}\text { Mailed survey } \\
\text { Misener Nurse Practitioner } \\
\text { Job Satisfaction Scale }\end{array}$ & $\begin{array}{l}\text { Demographic data, practice area, education } \\
\text { level, years of experience, specialty, } \\
\text { membership in a professional organization, } \\
\text { annual regular income, annual bonus pay, } \\
\text { regular weekly hours, on-call days, number } \\
\text { of patients seen daily }\end{array}$ & $\begin{array}{l}\text { A small positive correlation } \\
\text { between regular income and } \\
\text { job satisfaction for those } \\
\text { employed full-time }(\mathrm{r}=0.155 \text {, } \\
\mathrm{p}<0.05) \text {. } \\
\text { Bonus pay was positively } \\
\text { correlated with job } \\
\text { satisfaction in the total } \\
\text { population }(\mathrm{r}=0.210, \mathrm{p}<0.01) \text {. }\end{array}$ \\
\hline $\begin{array}{l}\text { Wyatt and } \\
\text { Harrison } \\
\text { (2010)[16] } \\
\text { USA }\end{array}$ & $\begin{array}{l}1,353 \text { certified } \\
\text { pediatric nurses in } \\
\text { Gaithersburg }\end{array}$ & $\begin{array}{l}\text { Mailed survey } \\
\text { Survey developed by } \\
\text { Pediatric Nursing } \\
\text { Certification Board nurse } \\
\text { researchers and experts }\end{array}$ & $\begin{array}{l}\text { Relationship with colleagues, supportive } \\
\text { work environment, relationship with } \\
\text { supervisors, benefits, workload, pay, } \\
\text { interactions with physicians, employer } \\
\text { recognition for certified pediatric nurses, } \\
\text { performance recognition, employer financial } \\
\text { support for continuing education, } \\
\text { opportunities for advancement, employer } \\
\text { mentoring programs }\end{array}$ & $\begin{array}{l}\text { Overall, } 63.2 \% \text { and } 66.2 \% \text { of } \\
\text { respondents indicated that } \\
\text { salary and benefits, } \\
\text { respectively, were important } \\
\text { factors that contributed to their } \\
\text { personal job satisfaction level. }\end{array}$ \\
\hline $\begin{array}{l}\text { Tao et al., } \\
\text { (2011)[17] } \\
\text { China }\end{array}$ & $\begin{array}{l}1,278 \mathrm{RNs} \text { in } \\
\text { northern and } \\
\text { southern China }\end{array}$ & $\begin{array}{l}\text { Convenience sampling } \\
\text { Chinese Nurses Job } \\
\text { Satisfaction Scale }\end{array}$ & $\begin{array}{l}\text { Administration, workload, co-workers, work } \\
\text { itself, salary, professional opportunities, } \\
\text { praise/recognition, family/work balance }\end{array}$ & $\begin{array}{l}\text { Annual income was not } \\
\text { significantly correlated with } \\
\text { job satisfaction. } \\
\text { Nurses in northern China, who } \\
\text { received less income than } \\
\text { nurses in southern China, } \\
\text { showed greater job } \\
\text { satisfaction than nurses in } \\
\text { southern China. } \\
\end{array}$ \\
\hline $\begin{array}{l}\text { Choi et al., } \\
\text { (2011)[18] } \\
\text { Hong } \\
\text { Kong }\end{array}$ & 26 frontline RNs & $\begin{array}{c}\text { Snowball sampling } \\
\text { Individual semi-structured } \\
\text { interviews }\end{array}$ & $\begin{array}{l}\text { Nursing work, environment, staffing level, } \\
\text { work responsibility, management, coworker } \\
\text { relationship, job incentives, professional } \\
\text { incentives, perceived nursing work } \\
\text { environment } \\
\end{array}$ & $\begin{array}{l}\text { The majority of the nurses } \\
\text { were generally satisfied with } \\
\text { the financial aspect and } \\
\text { commented that the job offers } \\
\text { a stable income. }\end{array}$ \\
\hline $\begin{array}{l}\text { Lambrou } \\
\text { et al., } \\
\text { (2010) [19] } \\
\text { Cyprus, } \\
\text { Europe }\end{array}$ & $\begin{array}{l}67 \text { doctors and } \\
219 \text { nurses in a } \\
\text { Cyprus public } \\
\text { general hospital }\end{array}$ & $\begin{array}{l}\text { Convenience sampling } \\
\text { An instrument developed } \\
\text { based on Maslow's and } \\
\text { Herzberg's theories }\end{array}$ & $\begin{array}{l}\text { Job attributes, remuneration, coworkers, } \\
\text { achievements }\end{array}$ & $\begin{array}{l}\text { High satisfaction at work was } \\
\text { positively and significantly } \\
\text { associated with higher scores } \\
\text { in remuneration, which was } \\
\text { associated with female gender, } \\
\text { fewer years in service and } \\
\text { occupying a managerial } \\
\text { position among the nurses. }\end{array}$ \\
\hline $\begin{array}{l}\text { Murrels et } \\
\text { al., (2008) } \\
\text { [20] } \\
\text { United } \\
\text { Kingdom } \\
\end{array}$ & $\begin{array}{l}\text { 3,962 nurses from } \\
\text { adult, children, } \\
\text { mental health and } \\
\text { learning disability } \\
\text { branches }\end{array}$ & $\begin{array}{c}\text { Convenience sampling } \\
\text { Self-developed } \\
\text { questionnaire distributed at } \\
\text { six months, } 18 \text { months and } \\
\text { three years } \\
\end{array}$ & $\begin{array}{l}\text { Education, work-life interface, resources, } \\
\text { salary }\end{array}$ & $\begin{array}{l}\text { Nurses were the least satisfied } \\
\text { with their salary. }\end{array}$ \\
\hline
\end{tabular}

Considering the above mentioned issues in Table 1 regarding the nursing manpower shortage, the nurse managers in a public hospital in Macao had a greater concern about the policy establishing the salary and employee benefits scheme [6]. For a private hospital in Macao, nurses were given 15 months of salary to be retained as the nursing staff. A quantitative locally conducted study showed that salary and employment benefits should be increased (96.6\%), with participation from 467 nursing staff, which was a $62.85 \%$ response rate [3]. Because of the above reasons, a bill for the ranking and grading system was recently successfully modified. Therefore, the aim of this study was to discuss the major difference in the elements of the bill of the Rank and Grade System from the past policy and the present modified policy to investigate whether the administrative management logically and critically modified the so-called unreasonable and out-of-date issues

\section{Methods}

\subsection{Methodology}

This present descriptive report used the major theme and item outcomes from the quantitative and qualitative approaches to evaluate whether the policy modification addressed the concerns of the frontline RNs with regard to salary and employee benefits. The research project was 
approved by the Management Board of the Research Committee at the Macao Polytechnic Institute. In the quantitative approach, 13 nurse managers from public or private hospitals or clinics and health-care centers were interviewed about their daily work-related problems and concerns on the wards (please refer to the details in the Leong (2012) article in the Journal of Nursing Management). One of the major themes among the interviewees was the low salary and poor employee benefits. Then, a descriptive design study, containing seven categories with 57 items, was conducted among the nursing staff that worked in the public sector in one acute-care hospital, one mental hospital and six health-care centers in all six geographic regions of Macao (please refer to Leong et al. (2012) in the International Journal of Nursing Science). The research outcomes show that more than $96.6 \%$ of the nurses strongly agreed or agreed that the "salary payment and employee benefits should be increased". The nurses also agreed with statements such as the "salary and benefits did not keep up with inflation" (92.9\%), the "payment did not reflect their great responsibilities and pressure" (91.2\%), the facilities should "allocate more resources to the wages and benefits of the nurse" (96.4\%), the "salary does not reflect educational qualifications" (89.3\%) and the facilities should "provide extra time and financial incentives for nurses during training” (96.1\%).

\subsection{Procedure}

This report used sources of information including publicly accessible published materials from the health bureau, social welfare bureau and public sector for documents and records and ward managers for information confirmation.

\subsection{Findings}

The introduction of the modified policy appears to have satisfied many of the nurses. Meanwhile, to attract new recruits for the nursing staff, the entry salary for nurses was raised from the original 340 points to 430 points on the salary scale, and the salary increase for each rank would range from 23 to $42 \%$ under the bill of the Rank and Grade System [21]. Starting in May 2012, one point equals MOP\$66 (US\$1.00 = MOP\$8.00). Therefore, a newly recruited nurse would be paid at least US\$3,359.37 (equivalent to MOP\$26,875) monthly, with the potential for additional types of allowances (Detail in Table 2). This salary is more than one and half times the median monthly earnings of the employed population in Macao (4th quarter/2011), which was US\$1,250.05 per month on average [22]. The increased salary was large for all of the nursing staff, even the experienced nurses who also had benefits based on their number of working years. In addition, the salary for shift duty, such as afternoon or night shifts, were increased, and overtime now provides up to double pay (after 22:00 and at least 0.75 times the basic salary (for weekday regular office hours). Some nurses did not mind working on shift duty, holidays or weekends, which is likely due to the sharp changes in salary, which is the most common important element responsible for the nursing shortage [9-10]. This basic salary excludes employment benefits, such as on-shift allowance and family subsidies. As a result, the total salary for one month will increase by more than US $\$ 1,000$ compared with the previous salary rank and grade scheme. In addition, there are more positions for promotions among the nursing staff, such as ranks for specialists, ward nurse managers and supervisors. In addition, the preliminary training course has been adapted to train the newly graduated nurses for six months to work in the medical and surgical wards, with a few additional hours devoted to theoretical knowledge.

The allowance for working experience after five and 10 years has also been adjusted, increasing by $194.4 \%$ and $177.8 \%$, respectively. The most noticeable changes involve overtime pay and on-shift allowances, with the percentage of salary and employee benefits being increased more than expected. Overall, these increases are larger than those provided in a report from the USA that stated that wages will have to increase by at least 50\% of the present wages by 2016 [23] to retain RNs. The concept of allowance in this modification is expected to increase the time spent working with a consequent increase in salary. One category of rank scheme, the senior specialist nurse, was added to the previous five categories of nurse, senior nurse, specialist nurse, ward manager and supervisor. In addition, two more positions have been added to the old policy. A summary of the old and new policies is shown in Table 2 
Table 2. Summary of the special modifications to the bill of the Rank and Grade System

\begin{tabular}{|c|c|c|c|}
\hline Policy & Past & Present & Results/Outcomes \\
\hline \multirow[b]{2}{*}{$\begin{array}{l}\text { Starting salary } \\
\qquad(\mathrm{MOP} \$)\end{array}$} & 22, 440 (newly recruited RNs) & 28,380 & Difference of > \$5000 (MOP\$) \\
\hline & $\begin{array}{c}\text { 24,420 (senior RNs) } \\
\text { 28,050 (specialist RNs) } \\
\text { N/A (senior specialist RNs) } \\
\text { 29,040 (ward manager) } \\
\text { 32,340 (supervisor rank) } \\
\end{array}$ & $\begin{array}{l}31,350 \\
33,660 \\
36,300 \\
39,600 \\
46,200 \\
\end{array}$ & Large increase in salary for all ranks \\
\hline $\begin{array}{l}\text { Years of working } \\
\text { allowance }\end{array}$ & $\begin{array}{c}@ \$ 180 \text { after five years } \\
@ \$ 360 \text { after } 10 \text { years } \\
\end{array}$ & $\begin{array}{l}@ \$ 500 \text { after five years } \\
@ \$ 1000 \text { after } 10 \text { years } \\
\end{array}$ & Significant improvement \\
\hline \multirow{2}{*}{$\begin{array}{l}\text { Overtime } \\
\text { allowance }\end{array}$} & Not clearly written & $\begin{array}{l}\text { Varies from } 0.75 \text { times to two times } \\
\text { the maximum of the monthly salary }\end{array}$ & $\begin{array}{c}\text { Willingness to pay for overtime if RNs are } \\
\text { available }\end{array}$ \\
\hline & Maximum of $30 \%$ of monthly salary & Maximum of $25 \%$ of monthly salary & $\begin{array}{l}\text { Illegal to force RNs to work after reaching } \\
\text { the maximum workload }\end{array}$ \\
\hline Shift allowance & $\$ 1,500$ fixed & $\begin{array}{l}\text { Flexible, the more on shift, especially } \\
\text { on Saturday, Sunday and holidays, } \\
\text { the higher the allowance will be, and } \\
\text { the shift allowance will also be } \\
\text { determined based on tenure }\end{array}$ & $\begin{array}{l}\text { Fair to reward RNs working on weekends } \\
\text { or holidays }\end{array}$ \\
\hline Rank scheme & 5 categories & $\begin{array}{l}6 \text { categories, with the senior specialist } \\
\text { position added }\end{array}$ & More ranks/positions for promotion \\
\hline Top management & 5 positions for supervisors & 7 positions for supervisors & $\begin{array}{l}\text { More positions; a decrease in the workload } \\
\text { of the supervisors }\end{array}$ \\
\hline $\begin{array}{c}\text { Special } \\
\text { administrative } \\
\text { position }\end{array}$ & One position for director & One position for director & \\
\hline
\end{tabular}

Note: According to the latest salary point system, one point is MOP $\$ 66$ (US\$1.00 is equivalent to MOP\$8.00).

\section{Discussion}

\subsection{Personal and Professional Level Benefits}

The new policy has been changed to favor RNs working in a ward with patients with more acute conditions and higher care needs. The job dissatisfaction in the acute wards is higher compared with health-care centers where the RNs are mostly needed to work on weekdays with regular office hours [3]. Therefore, the allowances for overtime work and on-shift duty in the wards have been modified (Figure 1). The overtime pay was also increased, ranging from 0.75 times the pay of a regular weekday shift for overtime to up to twice as much for holidays, weekends and night shifts. Both new and experienced nurses consider the regular day time work hours to be the best, i.e., from 9 am to 5:30 pm. The quantitative survey [3] revealed that the nursing staff is $92.9 \%$ female, with $61.6 \%$ being married. Therefore, in the past, most of the nursing staff wanted to shift their workplace to health-care centers or outpatient clinics that only require light duty, such as documentation, patient teaching and assisting medical doctors with basic treatments. The number of such requests has already been greatly reduced. Recently, the nursing staff is no longer against working in the acute ward and now prefers working overtime on holidays or weekends. This change is due to the attractiveness of the current employee benefits. Even the RNs in the UK have relocated to Australia to work as nurses due to the better financial package [24].

The rank scheme for nursing posts has added the category of "senior specialist" and two positions for supervisors, meaning that the new policy has seven supervisors in charge of a variety of wards. This new rank and additional positions will motivate more RNs to improve their knowledge and/or skills.

\subsection{Health Care Institution Level Benefits}

From the point-of-view of the economic market, even though a health-care institution provides patient care, the better its name-brand, the better its business will be. Only a few months ago, the public sector received a high score for the 47 criteria for the accreditation by the Australia Accreditation Hospital Standards, with the various medical, surgical and critical wards all passing that evaluation. These outcomes were much better than expected. Fewer complaints from residents have been reported in the media. Two of the three criteria for professional nursing were marked as excellent: the strategy and procedures to assess and evaluate nursing skills in the prevention of patient falls and patient ulcers.

\subsection{Society Level Benefits}

The population of Macao will benefit from the increased quality of care from professional health care services. The new policy now allows only those RNs with bachelor's degree to enter this field. There are many research studies showing that a nursing staff with a bachelor of science in nursing (BSN) can provide better patient care, critical thinking skills and health education [25-27]. 



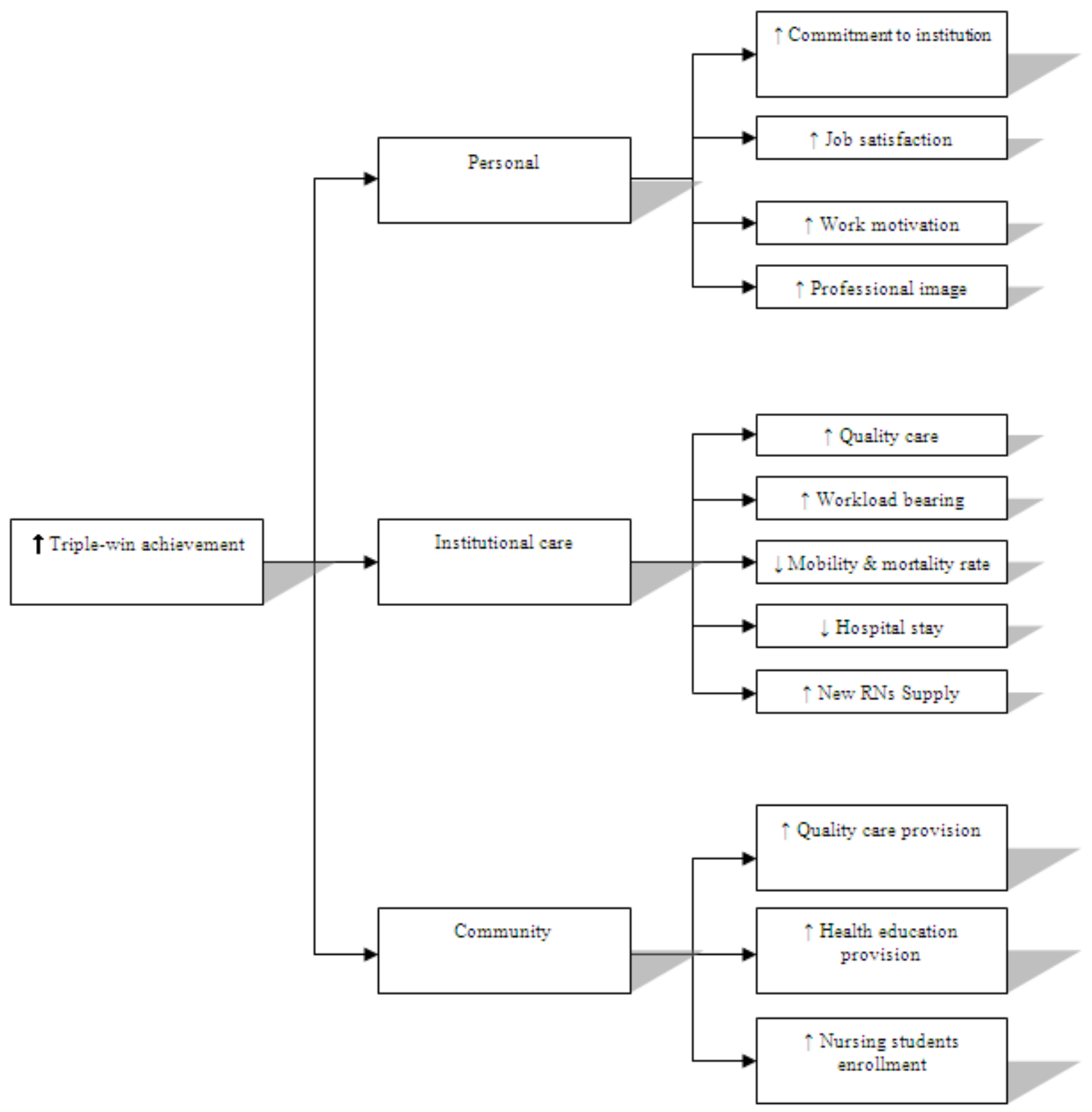

Figure 1. Expectation of the win-win-win situation benefits.

\subsection{Academic Nursing Schools Benefits}

In the past, approximately 70 nursing students graduated annually from the two nursing schools in Macao. Beginning this year, the number of new graduates will be increased to approximately one hundred. These students are all trained in a 4-year academic program leading to a Bachelor of Science in nursing (BSN). There is a trend that new BSN graduate nurses are in more demand [28]. Hence, each school increased their enrollment of nursing students, which can be credited to the great support provided by the policy of the Macao government. Given the approximate doubling of the number of registered nursing students, the nursing academic faculties have employed individuals with higher education levels. One nursing school recently employed five nursing educators (a 55.6\% increase) over the past four years.
In addition, more clinical instructors are paid to supervise nursing students during clinical practicum, resulting in a $100 \%$ increase in the payment rate.

\section{Conclusions}

The Macao government has tried to identify many strategies to quickly reduce the nursing manpower shortage by increasing the most basic financial incentives for the nursing staff. The package for the salary and employee benefits has been well received by the RNs. Even newly graduated students from secondary schools are now very interested in enrolling as nursing students. Because of the attractive salary rank and the high levels of advertisements, media programs and announcements, there is strong support 
and easier promotions to induce or attract high school graduates. These improvements are a credit to the excellent strategies of the policy modification.

\section{Limitations}

No research studies or surveys support the circumstances of whether the job satisfaction has improved after the policy modification, although many nurses mentioned an increased job satisfaction to the author. These observations may not apply to the actual experiences of the overall nursing staff working in the public health care industry. Further research is needed to cover all of the benefits for the nursing staff to obtain the feedback required to perform data analyses in this public health care system.

\section{REFERENCES}

[1] Health Bureau. (2012). Introduction of health Bureau, Government of Macao Special Administrative Region. Retrieved March 03, 2012 from http://www.ssm.gov.mo/desi gn/introduction/e_introduce_fs.htm

[2] Social Welfare Bureau (2012). Our ten year plan 1999-2009 (In Chinese). Social Welfare Brueau of MSAR Government. Retrieved March 03, 2012 from http://www.ias.gov.mo/abou tus/

[3] Leong, C. S. U., Ken, G., \& Liu, M. (2012). Findings from a quantitative approach of nurses possibly related to the nursing shortage before policy modification in Macao. International of Journal of Nursing Science 2(1), 1-7.

[4] Patrician, P. A., Shang, J., \& Lake, E. T. (2010). Organizational determinants of work outcomes and quality care ratings among army medical department registered nurses. Research in Nursing \& Health, 33(2), 99. Retrieved fromhttp://search.proquest.com/docview/222744354?accoun tid $=12207$

[5] Coomber, B., \& Barriball, K. L. (2007). Impact of job satisfaction components on intent to leave and turnover for hospital-based nurses: a review of the research literature. International Journal of Nursing Studies, 44(2), 297-314.

[6] Leong, C. S. U. (2012). Factors contributing to contemporary nursing shortage in Macao. Journal of Nursing Management, 20(4), 491-501.

[7] Spetz, J., Rickles, J., Chapman, S., \& Ong, P. M. (2008). Job and industry turnover for registered and licensed vocational nurses. Journal of Nursing Administration, 38(9), 372-378.

[8] Wilson, B., Squires, M., Widger, K., Cranley, L., \& Tourangeau, A. (2008). Job satisfaction among a multigenerational nursing workforce. Journal of Nursing Management, 16(6), 716-723.

[9] Beu, B. (2004). The nursing shortage and the Nurse Reinvestment Act. AORN J, 79 (5), 1061-1063.

[10] Spetz, J., \& Adams, S. (2006). How can employment-based benefits help the nurse shortage? Making nursing more attractive involves more than just wage levels. Health Affairs, 25 (1), 212-218.

[11] Wieck, K. L., Dols, J., \& Northam, S. (2009). What nurses want: the nurse incentives project. Nursing Economic\$, 27(3) 169-201.

[12] Hegney, D., Plank, A., \& Parker V. (2006) Extrinsic and intrinsic work values: their impact on job satisfaction in nursing. Journal of Nursing Management. 2006; 14: 271-281.

[13] Chen, K.Y., \& Chen, P.B. (2011, May 10). Public hospital lost $70 \%$ of experienced nurses especially in obstetrics and pediatrics units (in Chinese). Apple Daily News, p. A6.

[14] Ming Pao Special Report (2011, May 10). Legislation re-quested Health Bureau to submit the nursing manpower re-source planning (in Chinese). Ming Pao News, p. A6.

[15] Dunaway, A.I. (2008). Job Satisfaction among Nevada Nnurse practitioners (Master Thesis). Retrieved July 08, 2012 from ProQuest Dissertations and Theses database. (UMI No: 1453535).

[16] Wyatt, J., \& Harrison, M. (2010). Certified Pediatric Nurses' Perceptions of Job Satisfaction. Pediatric Nursing, 36 (4), 205-208.

[17] Tao, H., Zhang, A., Hu, J., \& Zhang, Y. (2011). Regional differences in job satisfaction for mainland Chinese nurses. Nursing Outlook, in press. Epub ahead of print. Retrieved June 01, 2012 from http://www.ncbi.nlm.nih.gov/pubmed/22 000688 .

[18] Choi, S.P., Pang, S.M., Cheung, K., \& Wong, T.K. (2011). Stabilizing and destabilizing forces in the nursing work environment: a qualitative study on turnover intention. Internal Journal of Nursing Studies, 48, 1290-1301.

[19] Lambrou, P., Kontodimopoulos, N., Niakas, D. (2010). Motivation and job satisfaction among medical and nursing staff in a Cyprus public general hospital. Human Resources for Health, (1), 26-36.

[20] Murrells, T., Robinson, S., \& Griffiths, P. (2008) Job satisfaction trends during nurses' early career. BMC Nursing 7 (7). Retrieved June 03, 2012, from http://www.biomedcentral.com/1472-6955/7/7.

[21] Macao Yearbook (2009). Government Information Bureau of the MSAR. Retrieved February 26, from http://www.gcs.gov.mo/

[22] Statistics and Census Service (2012). Employment Statistics: Median monthly earnings of employed population (4th Quarter/2011) (MOP), Government of Macao Special Administrative Region. Retrieved February 26, 2012, from http://www.dsec.gov.mo/Statistic.aspx

[23] Spetz, J., Given, R. (2012). The future of the nurse shortage: will wage increases close the gap? Health Affairs 22(6) 199-206. Retrieved February 23, 2012, from http://content.healthaffairs.org/ content/22/6/199.full.html.

[24] Dreaper, J. (2008). The Royal College of Nursing has warned that too many UK nurses are being lured to work in Australia. Story from BBC NEWS. Retrieved May 30, 2012, from http://news.bbc.co.uk/go/pr/fr/-/2/hi/health/7308073.stm.

[25] Aiken, L.H., Clarke, S.P., Cheung, R.B., Sloane, D.M, \& 
Silber, J.H. (2003). Educational levels of hospital nurses and surgical patient mortality. Journal of the American Medical Association, A 290 (12), 1617-1623.

[26] Mignor, D., Cadenhead, G., \& McKee, A. (2002). High school counselors' knowledge of professional nursing as a career option. Nursing Education Perspectives, 23 (2), 86-88.

[27] Wong, K.S., Wong, J.Y., Hua, J.Y., Zhang, J.B., \& Ba, B.D.
(2003). Twenty first century research report: Macao professional nursing care and continuous nurse education policy development (Chinese version). The Hong Kong Polytechnic University, 1-47.

[28] EL-Jardali, F., Merhi, M., Jamal, D., Dumit, N., \& Mouro, G. (2009). Assessment of nurse retention challenges and strategies in Lebanese hospitals: the perspective of nursing directors. Journal of Nursing Management, 17, 453-462. 